\title{
Serum estrogen and its soluble receptor levels in Egyptian patients with acute leukemia: case-control study
}

\author{
Samir Ali Abd El-Kaream', Samia Abd El-Moneim Ebied ${ }^{1}$, Nadia Ali Sadek², Dina Mohamed Saad ${ }^{1}$ and \\ Eman Attia Nadwan ${ }^{3^{*}}$ (D)
}

\begin{abstract}
Background: Acute leukemias are malignant neoplastic diseases that arise from either lymphoid [ALL] or myeloid [AML] cell lines that are distinguished by the proliferation of BM non-functional immature cells and subsequently released into the bloodstream. ALL is prevalent malignancy in young, while AML in older. Diagnosis is usually routinely performed through peripheral blood count and smear then confirmed by BM aspirate. It is remarkable to notice that leukemia can be manifested at high, low, and even at normal leucocyte count. While treatment results have improved steadily over the last decades in younger and adults, limited changes have been in survival among subjects of age $>60$ years. Aim of the work is to measure the serum estrogen [E2] and its soluble receptor [ER] levels in acute leukemia patients and extrapolate its possible clinical significance. This study included 40 [20 females and 20 males] healthy volunteers clinically free from any disease, 40 [20 females and 20 males] AML patients, and 40 [20 females and 20 males] ALL. To all subjects, serum E2 and its soluble ER level were investigated by ELISA.
\end{abstract}

Results: Serum E2 [pg/ml] level was lower in AML and ALL female and male patients groups than control group. Serum ER [ng/ml] level was lower in AML and ALL female and male patients groups than control group.

Conclusion: Estimation of serum E2 and its soluble ER level is of edifying diagnostic value. Determination of serum E2 and its soluble ER level in AML and ALL patients is of value in deciding treatment therapeutic target protocol.

Keywords: Estrogen, Estrogen receptor, Acute leukemia

\section{Background}

Acute leukemia is a bone marrow $[\mathrm{BM}]$ malignant disease in which the normal hematopoietic marrow cells replaced by an early proliferative myeloid or lymphoid precursors [1-3]. Acute leukemias are characterized upon their differentiation into lymphoid or myeloid lineages. In acute lymphoblastic leukemia (ALL), the abnormal proliferation in immature lymphocytes or lymphoid progenitor cells [4].

Two major types of ALL are known B-ALL and TALL. AML implicates the myeloid series from which

\footnotetext{
* Correspondence: Eman.nadwan@alexmed.edu.eg

${ }^{3}$ Department of Internal Medicine, Hematology Unit, Faculty of Medicine,

Alexandria University, Alexandria, Egypt

Full list of author information is available at the end of the article
}

neutrophils, eosinophils, basophils, monocytes, and megakaryocytes are derived [5, 6]. Each leukemia type has its own morphological cytochemical and immunological differences, different prognostic markers, and lines of treatment. Prognostic factors could predict treatment outcome in acute leukemia patients, either complete remission after chemotherapy or disease resistance to conventional protocols [7]. A single prognostic factor cannot reliably predict prognosis, but it must be correlated with all available information [8].

Estrogen negatively regulates BM cells proliferation, which turn into progenitors of myeloid and lymphoid. Moreover, significant bone marrow hematopoiesis alteration is present in estrogen insufficiency and in ER knockout mice [9]. Estrogen functions through alpha 
ER- $\alpha$ and beta ER- $\beta$ receptor [10]. Estrogen receptor gene is present on chromosome 6 long arm, which is often altered in hematopoietic neoplasms [11, 12]. In healthy controls, ER- $\alpha$ is unmethylated compared to acute leukemia patients; hence, it can act as an epigenetic biomarker of leukemia [12]. A previous study found that estrogen suppresses the stem cells differentiation into myeloid and lymphoid. In addition, serum estrogen [E2] has a negative effect which might be by ER- $\beta$ on immune system [13]. In vitro studies on leukemia have revealed various cytotoxic impact of clomiphen, a wellknown ER antagonist in breast cancer patients [14, 15].

\section{Aim of the work}

Measure the serum E2 and its soluble ER levels in acute leukemia patients and extrapolate its possible clinical significance as diagnostic markers.

\section{Methods}

Subjects submitted work were grouped into the following: group I, 40 healthy [20 females and 20 males] clinically free from any disease as control group and their age was $41.30 \pm 3.46$ years and were chosen from the stuff members and their relatives of university hematology unit; group II, 40 AML patients [20 females and 20 males]; and group III, 40 ALL patients [20 females and 20 males]. From all participants, informed consent was taken [recruited from MRI and Faculty of Medicine, Alexandria University Hematological unit] in this study.

\section{Exclusion criteria}

Subjects with former hematological disorders [myeloproliferative disorders, myelodysplastic syndromes, multiple myeloma, and lymphoproliferative disorders] prior received radio- or chemotherapy for mass neoplasm

\section{Regiments of treatment}

$45 \mathrm{mg} / \mathrm{m}^{2}$ Daunorubicin for 3 days and $100 \mathrm{mg} / \mathrm{m}^{2} \times 2$ / day cytosine arabinoside for a week made up the protocol for AML patients.

$1.4 \mathrm{mg} / \mathrm{m}^{2}$ Vincristine days $1,8,15$, and $22 ; 1 \mathrm{mg} / \mathrm{kg} /$ day Prednisolone $\times 28$ days; and $25 \mathrm{mg} / \mathrm{m}^{2}$ Doxorubicin days 1, 2, and 3 made up the protocol for ALL patients.

At the protocol end and restoration BM cellularity, aspiration of $\mathrm{BM}$ was taken. Less than $5 \%$ BM blasts were considered complete remission and 2nd induction cycle was taken by those who did not reach complete remission.

The subsequent investigations were performed for all subjects: complete history and clinical examination enrollment, complete blood picture [16], and some liver functions; AST, ALT, albumin, and some kidney functions; and urea, creatinine [17-20], bone marrow examination [21], flow cytometry to differentiate AML from
ALL [16], and determination of serum soluble ER level by ELISA [22], also E2 level by ELISA [23].

\section{Statistical analysis}

Data assessment by SPSS program V20.0, the K-S test was used to check normality. Results were represented as mean [range; min and max], median, and standard error. Significance was considered at 5\% level. F-test [ANOVA] and LSD test were used for quantitative variables [parametric]; Kruskal-Wallis test and Dunn's test Spearman coefficient for quantitative variables [nonparametric]; and ROC curve for diagnostic power of test measured by assessing area under curve also a comparison of performance between two tests.

\section{Results}

Serum ER level [ng/ml] in AML and ALL male/female patients and control group

The results showed that the level of serum ER $[\mathrm{ng} / \mathrm{ml}]$ in AML and ALL male patients was significantly lower than in male control group $\left[P_{1} \leq 0.001, P_{2}=0.002\right]$. While levels of ER in both groups of patients were insignificant about same range $\left[P_{3}=0.915\right]$ (Table 1 ).

The results showed that the level of serum ER $[\mathrm{ng} / \mathrm{ml}]$ in AML and ALL female patients was significantly lower than in female control group $\left[P_{1}=0.012, P_{2}=0.003\right]$. While, levels of ER in both groups of patients were insignificant about same range $\left[P_{3}=0.629\right]$ (Table 1$)$.

\section{Serum E2 level $[\mathrm{pg} / \mathrm{ml}]$ in AML and ALL male/female patients and control group}

The results showed that the level of serum E2 $[\mathrm{pg} / \mathrm{ml}]$ in AML and ALL male patients was significantly lower than in male control group $\left[P_{1}=0.001, P_{2}=0.005\right]$, while levels of E2 in both groups of patients were insignificant about same range $\left[P_{3}=0.920\right]$ (Table 1 ).

The results showed that the level of serum E2 [pg/ml] in AML and ALL female patients was significantly lower than in female control group $\left[P_{1}=0.009, P_{2}=0.041\right]$. While, levels of E2 in both groups of patients were insignificant about same range $\left[P_{3}=0.059\right]$ (Table 1$)$.

\section{Serum ER level [ng/ml] in AML [M4+M5] and AML [other subtypes] male/female patients}

The results showed that level of serum ER $[\mathrm{ng} / \mathrm{ml}]$ in AML [M4 + M5] male patients was insignificantly lower than in AML [other subtypes] patients (Table 2).

The results showed that level of serum ER $[\mathrm{ng} / \mathrm{ml}]$ in AML [M4 + M5] female patients was insignificantly higher than in AML [other subtypes] patients (Table 2). 
Table 1 Serum ER level (ng/ml) and E2 level $(\mathrm{pg} / \mathrm{ml})$ in AML and ALL male/female patients and control group

\begin{tabular}{llll}
\hline & Control $(\boldsymbol{n}=\mathbf{2 0})$ & AML $(\boldsymbol{n}=\mathbf{2 0})$ & ALL $(\boldsymbol{n}=\mathbf{2 0})$ \\
\hline \multicolumn{2}{l}{ ER $(\mathbf{n g} / \mathbf{m l})$ in male } & & \\
Range & $1.17-9.27$ & $0.36-14.11$ & $0.30-2.47$ \\
Mean \pm SE & $5.67 \pm 0.81$ & $1.91 \pm 0.75$ & $1.24 \pm 0.26$ \\
Median & 5.08 & 0.75 & 0.98 \\
$\boldsymbol{H}(\boldsymbol{p})$ & $15.485^{*}\left(<0.001^{*}\right)$ & & \\
$\boldsymbol{p}_{\mathbf{1}}$ & $<0.001^{*}$ & & \\
$\boldsymbol{p}_{\mathbf{2}}$ & $0.002^{*}$ & & \\
$\boldsymbol{p}_{\mathbf{3}}$ & 0.915 &
\end{tabular}

$\operatorname{ER}(\mathrm{ng} / \mathrm{ml})$ in female

$\begin{array}{llll}\text { Range } & 0.72-7.75 & 0.51-11.30 & 0.24-1.67 \\ \text { Mean } \pm \text { SE } & 5.29 \pm 0.81 & 2.37 \pm 1.09 & 0.94 \pm 0.11 \\ \text { Median } & 5.66 & 0.96 & 0.94 \\ \boldsymbol{H ( p )} & 10.278^{*}\left(0.006^{*}\right) & & \\ \boldsymbol{p}_{\mathbf{1}} & 0.012^{*} & & \\ \boldsymbol{p}_{\mathbf{2}} & 0.003^{*} & & \\ \boldsymbol{p}_{\mathbf{3}} & 0.629 & & \end{array}$

$\mathrm{E} 2(\mathrm{pg} / \mathrm{ml})$ in male

\begin{tabular}{llll} 
Range & $10.80-44.10$ & $2.70-69.80$ & $3.20-33.40$ \\
Mean \pm SE & $29.96 \pm 3.12$ & $15.07 \pm 3.90$ & $12.52 \pm 3.64$ \\
Median & 31.80 & 8.61 & 10.10 \\
$\boldsymbol{H}(\boldsymbol{p})$ & $11.713^{*}\left(0.003^{*}\right)$ & & \\
$\boldsymbol{p}_{\mathbf{1}}$ & $0.001^{*}$ & & \\
$\boldsymbol{p}_{\mathbf{2}}$ & $0.005^{*}$ & & \\
$\boldsymbol{p}_{\mathbf{3}}$ & 0.920 & & $2.80-20.80$ \\
$\mathbf{2}(\mathbf{p g} / \mathbf{m L})$ in female & & $8.80 \pm 1.60$ \\
Range & $2.90-154.0$ & $2.50-16.70$ & 7.70 \\
Mean \pm SE & $51.99 \pm 17.48$ & $5.70 \pm 1.41$ & \\
Median & 35.10 & 4.05 & \\
$\boldsymbol{H}(\boldsymbol{p})$ & $9.456^{*}\left(0.009^{*}\right)$ & & \\
$\boldsymbol{p}_{\mathbf{1}}$ & $0.009^{*}$ & & \\
$\boldsymbol{p}_{\mathbf{2}}$ & $0.041^{*}$ & & \\
$\boldsymbol{p}_{\mathbf{3}}$ & 0.059 & & \\
\hline
\end{tabular}

$H, p, H$ and $p$ values for Kruskal-Wallis test. Pairwise comparison bet. each of the 2 groups was done using post hoc test (Dunn's for multiple comparisons test). $p_{1}, p$ value for comparing between control group and AML group; $p_{2}, p$ value for comparing between control group and ALL group; and $p_{3}, p$ value for comparing between AML group and ALL group *Statistically significant at $p \leq 0.05$

Serum E2 level [pg/ml] in AML [M4+M5] and AML [other subtypes] male/female patients

The results showed that level of serum E2 $[\mathrm{pg} / \mathrm{ml}]$ in AML [M4 + M5] male patients was insignificantly lower than in AML [other subtypes] patients (Table 2).

The results showed that level of serum E2 $[\mathrm{pg} / \mathrm{ml}]$ in AML [M4 + M5] female patients was insignificantly lower than in AML [other subtypes] patients (Table 2).
Liver function parameters in AML and ALL patients groups and control subjects

The results showed that the mean value of AST levels [U/l] in ALL patients is significantly higher than in control group $\left[P_{2}=0.007\right]$. Moreover Table 3 showed that ALT levels [U/l] in AML and ALL patients were significantly higher than in control group $\left[P_{1} \leq 0.001, P_{2} \leq\right.$ 0.001]. While, serum albumin concentration $[\mathrm{mg} / \mathrm{dl}]$ in AML and ALL patients were significantly lower than in control group $\left[P_{1}=0.024, P_{2}=0.007\right]$ (Table 3 ).

\section{Kidney function parameters in AML and ALL patients and control group}

The results showed that in AML and ALL patients, the mean values of serum urea concentration $[\mathrm{mg} / \mathrm{dl}]\left[P_{1} \leq\right.$ $\left.0.001, P_{2} \leq 0.001\right]$ and serum creatinine concentration $[\mathrm{mg} / \mathrm{dl}]\left[\mathrm{P}_{1}=0.034, P_{2} \leq 0.001\right]$ were significantly higher than in control group. Also, the mean value of serum creatinine concentration $[\mathrm{mg} / \mathrm{dl}]$ in ALL patients group was significantly higher than in those with $\mathrm{AML}\left[P_{3}=\right.$ 0.008] (Table 4).

\section{Mean values of WBC count $\left[\times 10^{3} / \mu \mathrm{l}\right]$, PLT count $\left[\times 10^{3} /\right.$ $\mu \mathrm{l}]$, and hemoglobin conc. $[\mathrm{g} / \mathrm{dl}]$ in $\mathrm{AML}$ and $\mathrm{ALL}$ patients and control group}

The results showed that WBCs count mean value in AML and ALL patients were higher than in control group $\left[P_{1}=0.014, P_{2} \leq 0.001\right]$, while $\mathrm{Hb}$ conc. and PLT count in both patients groups were lower than in control group $\left[P_{1} \leq 0.001, P_{2} \leq 0.001\right]$ (Table 5 ).

\section{Correlation of serum ER and E2 levels with different biochemical and hematological parameters in AML and ALL male/female group}

As presented in Table 6, level of ER $[\mathrm{ng} / \mathrm{ml}]$ in serum of AML male patients showed a significant positive correlation with $\mathrm{E} 2[\mathrm{pg} / \mathrm{ml}]\left[r_{\mathrm{s}}=0.472, p=0.044\right]$ and $\mathrm{Hb}$ concentration $[\mathrm{g} / \mathrm{dl}]\left[r_{\mathrm{s}}=0.472, p=0.048\right]$ and was negatively correlated with WBCs count $\left[\times 10^{3} / \mu \mathrm{l}\right]\left[r_{\mathrm{s}}=-\right.$ 0.489, $p=0.040]$ and age [years] $\left[r_{\mathrm{s}}=-0.729, P=\right.$ 0.001] (Table 6).

Our results showed that serum E2 $[\mathrm{pg} / \mathrm{ml}]$ was positively significantly correlated with ER $[\mathrm{ng} / \mathrm{ml}]\left[r_{\mathrm{s}}=\right.$ 0.636, $p=0.048]$ and $\mathrm{Hb}$ concentration [g/dl] $\left[r_{\mathrm{s}}=\right.$ 0.754, $p=0.012$ ] in AML female patients group. Also, it was noticed that level of serum ER [ng/ml] of ALL female patients showed a negative significant correlation with Blast cells $\left[r_{\mathrm{s}}=-0.665, p=0.036\right]$, while level of serum E2 $[\mathrm{pg} / \mathrm{ml}]$ of ALL female patients showed a negative significant correlation with albumin $[\mathrm{mg} / \mathrm{dl}]\left[r_{\mathrm{s}}\right.$ $=-0.661, p=0.038]$ (Table 6). 
Table 2 Serum ER level (ng/ml) and E2 level (pg/ml) in AML (M4+M5) and AML (other subtypes) male/female patients

\begin{tabular}{|c|c|c|}
\hline & AML (M4 + M5) $(n=10)$ & AML (others subtypes) $(n=10)$ \\
\hline \multicolumn{3}{|c|}{$\mathrm{ER}(\mathrm{ng} / \mathrm{ml})$ in male } \\
\hline Range & $0.36-3.58$ & $0.36-14.11$ \\
\hline Mean \pm SE & $1.42 \pm 0.39$ & $2.52 \pm 1.66$ \\
\hline \multicolumn{3}{|l|}{ Median } \\
\hline$U(p)$ & $38.500(0.894)$ & \\
\hline \multicolumn{3}{|c|}{ ER (ng/ml) in female } \\
\hline Range & $0.59-11.30$ & $0.51-5.40$ \\
\hline Mean \pm SE & $2.85 \pm 2.11$ & $1.90 \pm 0.89$ \\
\hline \multicolumn{3}{|l|}{ Median } \\
\hline$U(p)$ & $11.00(0.754)$ & \\
\hline \multicolumn{3}{|c|}{$\mathrm{E} 2(\mathrm{pg} / \mathrm{ml})$ in male } \\
\hline Range & $3.20-25.90$ & $2.70-69.80$ \\
\hline Mean \pm SE & $11.63 \pm 2.52$ & $19.38 \pm 8.25$ \\
\hline Median & 8.61 & 8.95 \\
\hline$U(p)$ & $39.500(0.965)$ & \\
\hline \multicolumn{3}{|c|}{ E2 $(\mathrm{pg} / \mathrm{mL})$ in female } \\
\hline Range & $2.60-6.14$ & $2.50-16.70$ \\
\hline Mean \pm SE. & $3.96 \pm 0.71$ & $7.43 \pm 2.64$ \\
\hline Median & 3.0 & 4.30 \\
\hline$U(p)$ & $9.00(0.465)$ & \\
\hline
\end{tabular}

$U$, Mann-Whitney test; $P, P$ value for comparing the two studied groups

Table 3 Liver functions in AML and ALL patients and control group

\begin{tabular}{|c|c|c|c|c|c|}
\hline Liver function & Control $(n=40)$ & $\mathrm{AML}(n=40)$ & ALL $(n=40)$ & Test of sig. & $p$ \\
\hline \multicolumn{6}{|l|}{ SGOT (U/I) } \\
\hline Range & $21.0-35.0$ & $9.0-100.0$ & $15.0-100.0$ & $H=7.444^{*}$ & $0.024^{*}$ \\
\hline Mean \pm SE & $28.20 \pm 1.10$ & $39.04 \pm 4.31$ & $48.21 \pm 5.73$ & & \\
\hline Median & 28.50 & 37.50 & 50.00 & & \\
\hline Sig. bet. grps & \multicolumn{5}{|c|}{$p_{1}=0.101, p_{2}=0.007^{*}, p_{3}=0.188$} \\
\hline \multicolumn{6}{|l|}{ SGPT(U/I) } \\
\hline Range & $10.0-19.0$ & $5.0-130.0$ & $30.0-110.0$ & $H=33.282^{*}$ & $<0.001^{*}$ \\
\hline Mean \pm SE & $15.30 \pm 0.83$ & $46.07 \pm 6.03$ & $53.34 \pm 4.73$ & & \\
\hline Median & 17.50 & 39.00 & 49.00 & & \\
\hline Sig. bet. grps & \multicolumn{5}{|c|}{$p_{1}<0.001^{*}, p_{2}<0.001^{*}, p_{3}=0.102$} \\
\hline \multicolumn{6}{|l|}{ Alb (mg/dl) } \\
\hline Range & $3.60-4.70$ & $2.40-4.90$ & $2.50-4.90$ & $F=5.632^{*}$ & $0.006^{*}$ \\
\hline Mean \pm SE. & $4.31 \pm 0.07$ & $3.83 \pm 0.13$ & $3.64 \pm 0.19$ & & \\
\hline Median & 4.40 & 3.80 & 3.60 & & \\
\hline Sig. bet. grps & \multicolumn{5}{|c|}{$p_{1}=0.024^{*}, p_{2}=0.007^{*}, p_{3}=0.485$} \\
\hline
\end{tabular}

$H, p, H$ and $p$ values for Kruskal-Wallis test. Pairwise comparison bet. each of the 2 groups was done using post hoc test (Dunn's for multiple comparisons test). $F$, $p, F$ and $p$ values for ANOVA test. Pairwise comparison bet. each of the 2 groups was done using post hoc test (LSD). $p_{1}, p$ value for comparing between control group and AML group; $p_{2}, p$ value for comparing between control group and ALL group; and $p_{3}, p$ value for comparing between AML group and ALL group *Statistically significant at $p \leq 0.05$ 
Table 4 Kidney functions in AML and ALL patients and control group

\begin{tabular}{|c|c|c|c|c|c|}
\hline Renal function & Control $(n=40)$ & AML $(n=40)$ & ALL $(n=40)$ & $H$ & $p$ \\
\hline \multicolumn{6}{|l|}{ Urea (mg/dl) } \\
\hline Range & $10.50-36.50$ & $9.0-200.0$ & $17.0-160.0$ & $23.784^{*}$ & $<0.001^{*}$ \\
\hline Mean \pm SE & $24.02 \pm 1.52$ & $46.07 \pm 6.75$ & $56.99 \pm 8.72$ & & \\
\hline Median & 23.80 & 40.00 & 40.00 & & \\
\hline Sig. bet. grps & \multicolumn{5}{|c|}{$p_{1}<0.001^{*}, p_{2}<0.001^{*}, p_{3}=0.444$} \\
\hline \multicolumn{6}{|l|}{$\mathrm{Cr}(\mathrm{mg} / \mathrm{dl})$} \\
\hline Range & $0.50-1.10$ & $0.50-5.0$ & $0.40-4.0$ & $19.388^{*}$ & $<0.001^{*}$ \\
\hline Mean \pm SE & $0.71 \pm 0.04$ & $1.11 \pm 0.17$ & $1.95 \pm 0.27$ & & \\
\hline Median & 0.67 & 0.80 & 1.30 & & \\
\hline Sig. bet. grps & \multicolumn{5}{|c|}{$p_{1}=0.034^{*}, p_{2}<0.001^{*}, p_{3}=0.008^{*}$} \\
\hline
\end{tabular}

$H, p, H$ and $p$ values for Kruskal-Wallis test. Pairwise comparison bet. each of the 2 groups was done using post hoc test (Dunn's for multiple comparisons test). $p_{1}$, $p$ value for comparing between control group and AML group; $p_{2}, p$ value for comparing between control group and ALL group; and $p_{3}, p$ value for comparing between AML group and ALL group

*Statistically significant at $p \leq 0.05$

Comparison between the values of serum ER and E2 as diagnostic marker for AML and ALL male/female patients groups

The ROC curve plot was applied for assessment the diagnostic values of serum ER [ng/ml] and E2 [pg/ml] based on the AUC. Serum ER showed significant AUC [0.926], $P[<0.001]$ with sensitivity and specificity [96.30\% and $90.0 \%$, respectively], and cut-off value [ $\leq$ $3.58 \mathrm{ng} / \mathrm{ml}$. Serum E2 $[\mathrm{pg} / \mathrm{ml}]$ showed significant AUC [0.870] $[P=0.001]$, with sensitivity and specificity [85.19\% and $80.0 \%$, respectively] (Table 7 and Fig. 1A).
The ROC curve plot was applied for assessment the diagnostic values of serum ER $[\mathrm{ng} / \mathrm{ml}]$ and E2 $[\mathrm{pg} / \mathrm{ml}]$ based on the AUC. Serum ER showed significant AUC $[0.880][P=0.001]$ with sensitivity and specificity $[90.0 \%$ and $90.0 \%$, respectively], and cut-off value $[\leq 1.67 \mathrm{ng} /$ $\mathrm{ml}$. Serum E2 [pg/ml] showed significant AUC [0.808] $[\mathrm{P}=0.005]$ with sensitivity and specificity $[100 \%$ and $60.0 \%$, respectively] (Table 7 and Fig. 1B).

\section{Discussion}

The role of estrogen receptor has been well established in cancer breast. Several studies have explored its role in

Table 5 Hematological parameters in AML and ALL patients and control group

\begin{tabular}{|c|c|c|c|c|c|}
\hline & Control $(n=40)$ & AML $(n=40)$ & ALL $(n=40)$ & Test of sig. & $p$ \\
\hline \multicolumn{6}{|l|}{ WBCs $\left(\times 10^{3} / \mu \mathrm{l}\right)$} \\
\hline Range & $3.20-10.0$ & $0.54-130.0$ & $1.0-170.0$ & $H=16.452^{*}$ & $<0.001^{*}$ \\
\hline Mean \pm SE & $6.01 \pm 0.45$ & $35.88 \pm 7.0$ & $56.76 \pm 10.25$ & & \\
\hline Median & 5.60 & 19.00 & 51.50 & & \\
\hline Sig. bet. grps & \multicolumn{5}{|c|}{$p_{1}=0.014^{*}, p_{2}<0.001^{*}, p_{3}=0.054$} \\
\hline \multicolumn{6}{|l|}{ PLTs $\left(\times 10^{3} / \mu \mathrm{l}\right)$} \\
\hline Range & $136.0-300.0$ & $6.0-296.0$ & $7.0-334.0$ & $H=35.230^{*}$ & $<0.001^{*}$ \\
\hline Mean \pm SE & $229.10 \pm 12.04$ & $65.11 \pm 10.66$ & $66.52 \pm 16.12$ & & \\
\hline Median & 228.50 & 50.00 & 54.00 & & \\
\hline Sig. bet. grps & \multicolumn{5}{|c|}{$p_{1}<0.001^{*}, p_{2}<0.001^{*}, p_{3}=0.945$} \\
\hline \multicolumn{6}{|l|}{$\mathrm{Hb}(\mathrm{g} / \mathrm{dl})$} \\
\hline Range & $9.80-14.0$ & $5.50-12.20$ & $4.50-12.70$ & $F=26.230^{*}$ & $<0.001^{*}$ \\
\hline Mean \pm SE & $11.90 \pm 0.29$ & $8.76 \pm 0.28$ & $8.52 \pm 0.50$ & & \\
\hline Median & 12.25 & 9.00 & 8.50 & & \\
\hline
\end{tabular}


Table 6 Correlation of ER and E2 with different biochemical and hematological parameters in male/female groups

\begin{tabular}{|c|c|c|c|c|c|c|c|c|}
\hline \multirow[t]{3}{*}{ Male } & \multicolumn{4}{|c|}{$\mathrm{AML}(n=20)$} & \multicolumn{4}{|c|}{$\operatorname{ALL}(n=20)$} \\
\hline & \multicolumn{2}{|l|}{ ER } & \multicolumn{2}{|l|}{ E2 } & \multicolumn{2}{|l|}{ ER } & \multicolumn{2}{|l|}{ E2 } \\
\hline & $r_{\mathrm{s}}$ & $p$ & $r_{\mathrm{s}}$ & $p$ & $r_{\mathrm{s}}$ & $p$ & $r_{\mathrm{s}}$ & $p$ \\
\hline $\mathrm{ER}(\mathrm{ng} / \mathrm{ml})$ & - & - & $0.472^{*}$ & $0.044^{*}$ & - & - & -0.317 & 0.406 \\
\hline E2 (pg/ml) & $0.472^{*}$ & $0.044^{*}$ & - & - & -0.317 & 0.406 & - & - \\
\hline Age (years) & $-0.729^{*}$ & $0.001^{*}$ & -0.335 & 0.174 & -0.343 & 0.366 & 0.075 & 0.847 \\
\hline $\mathrm{Hb}(\mathrm{g} / \mathrm{dl})$ & $0.472^{*}$ & $0.048^{*}$ & 0.184 & 0.465 & -0.167 & 0.667 & -0.100 & 0.797 \\
\hline WBCs $\left(\times 10^{3} / \mu \mathrm{l}\right)$ & $-0.489^{*}$ & $0.040^{*}$ & -0.322 & 0.192 & -0.183 & 0.637 & 0.233 & 0.546 \\
\hline PLTs $\left(\times 10^{3} / \mu \mathrm{l}\right)$ & -0.028 & 0.911 & 0.289 & 0.245 & -0.059 & 0.881 & -0.293 & 0.444 \\
\hline SGOT (U/I) & 0.001 & 0.998 & 0.028 & 0.912 & -0.151 & 0.698 & 0.160 & 0.682 \\
\hline SGPT (U/I) & 0.313 & 0.206 & 0.094 & 0.710 & 0.034 & 0.931 & 0.322 & 0.398 \\
\hline UR (mg/dl) & -0.080 & 0.751 & -0.181 & 0.471 & 0.339 & 0.372 & 0.051 & 0.897 \\
\hline $\mathrm{Cr}(\mathrm{mg} / \mathrm{dl})$ & -0.015 & 0.953 & -0.284 & 0.253 & -0.211 & 0.586 & 0.158 & 0.685 \\
\hline Blast cells & -0.013 & 0.961 & 0.032 & 0.899 & 0.042 & 0.914 & -0.498 & 0.173 \\
\hline Alb (mg/dl) & 0.160 & 0.526 & 0.330 & 0.182 & -0.351 & 0.354 & -0.251 & 0.515 \\
\hline \multirow[t]{3}{*}{ Female } & \multicolumn{4}{|c|}{ AML $(n=20)$} & \multicolumn{4}{|c|}{ ALL $(n=20)$} \\
\hline & \multicolumn{2}{|l|}{ ER } & \multicolumn{2}{|l|}{ E2 } & \multicolumn{2}{|l|}{ ER } & \multicolumn{2}{|l|}{ E2 } \\
\hline & $r_{\mathrm{s}}$ & $p$ & $r_{\mathrm{s}}$ & $p$ & $r_{\mathrm{s}}$ & $p$ & $r_{\mathrm{s}}$ & $p$ \\
\hline $\mathrm{ER}(\mathrm{ng} / \mathrm{ml})$ & - & - & $0.636^{*}$ & $0.048^{*}$ & - & - & 0.457 & 0.184 \\
\hline E2 (pg/ml) & $0.636^{*}$ & $0.048^{*}$ & - & - & 0.457 & 0.184 & - & - \\
\hline Age (years) & 0.358 & 0.310 & 0.176 & 0.627 & 0.236 & 0.511 & 0.156 & 0.668 \\
\hline $\mathrm{Hb}(\mathrm{g} / \mathrm{dl})$ & 0.353 & 0.318 & $0.754^{*}$ & $0.012^{*}$ & 0.363 & 0.302 & 0.227 & 0.529 \\
\hline WBCs $\left(\times 10^{3} / \mu \mathrm{l}\right)$ & -0.389 & 0.266 & -0.395 & 0.258 & 0.000 & 1.000 & -0.085 & 0.815 \\
\hline PLTs $\left(\times 10^{3} / \mu \mathrm{l}\right)$ & 0.134 & 0.712 & 0.561 & 0.092 & -0.068 & 0.853 & -0.109 & 0.763 \\
\hline SGOT (U/I) & -0.343 & 0.333 & -0.037 & 0.920 & 0.117 & 0.747 & 0.140 & 0.699 \\
\hline SGPT (U/I) & -0.366 & 0.298 & 0.098 & 0.789 & -0.209 & 0.562 & -0.158 & 0.663 \\
\hline UR (mg/dl) & -0.109 & 0.763 & 0.103 & 0.776 & -0.050 & 0.892 & -0.263 & 0.463 \\
\hline $\mathrm{Cr}(\mathrm{mg} / \mathrm{dl})$ & 0.306 & 0.390 & 0.128 & 0.724 & -0.588 & 0.074 & -0.543 & 0.105 \\
\hline Blast cells & 0.603 & 0.065 & 0.382 & 0.277 & $-0.665^{*}$ & $0.036^{*}$ & -0.534 & 0.112 \\
\hline Alb (mg/dl) & -0.219 & 0.544 & 0.067 & 0.854 & -0.526 & 0.118 & $-0.661^{*}$ & $0.038^{*}$ \\
\hline
\end{tabular}

is Spearman coefficient

*Statistically significant at $p \leq 0.05$

Table 7 ROC curves analysis of serum ER ( $\mathrm{ng} / \mathrm{ml})$ and E2 (pg/ml) in AML and ALL male/female patients groups

\begin{tabular}{clllll}
\hline & AUC & Asymptomatic significance & Cut-off & Sensitivity & Specificity \\
\hline Male & & & & \\
ER & $0.926^{*}$ & $<0.001^{*}$ & $\leq 3.58$ & 96.30 & 90.0 \\
E2 & $0.870^{*}$ & $0.001^{*}$ & $\leq 25.9$ & 85.19 & 80.0 \\
Female & & & & \\
ER & $0.880^{*}$ & $0.001^{*}$ & $\leq 1.67$ & 90.0 & 90.0 \\
E2 & $0.808^{*}$ & $0.007^{*}$ & $\leq 23.45$ & 100.0 & 60.0 \\
\hline
\end{tabular}




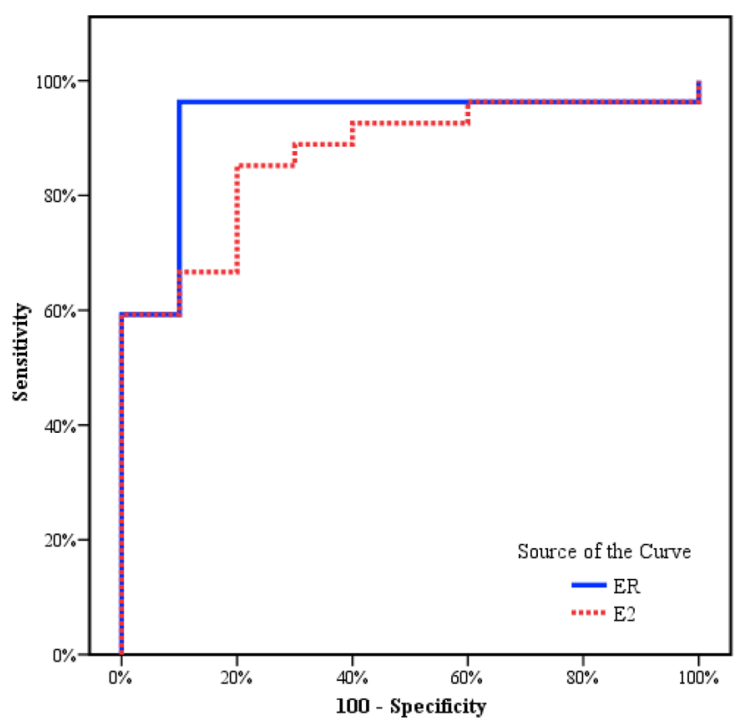

(a): Serum ER (ng/ml) and E2 (pg/ml) in AML and ALL male patients groups ROC curve

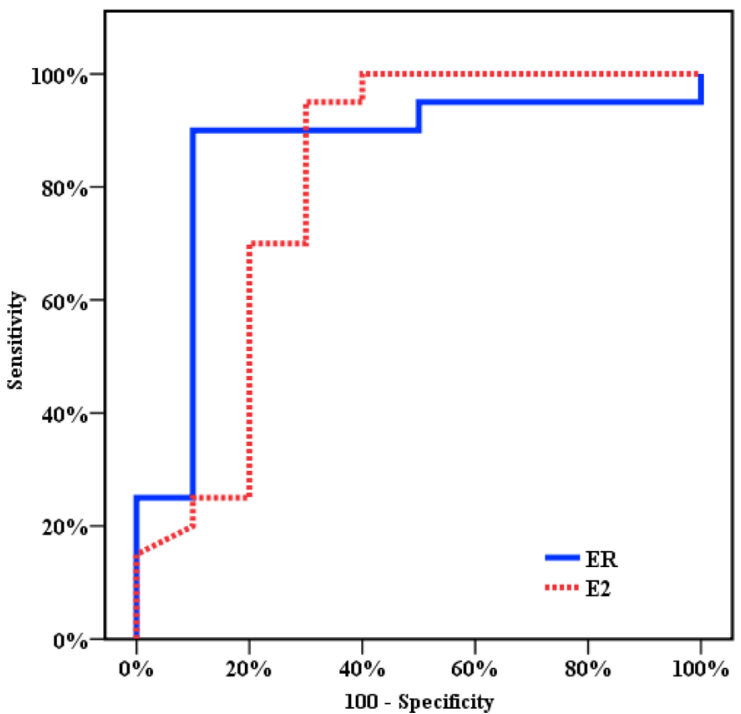

(b): Serum ER (ng/ml) and E2 (pg/ml) in AML and ALL female patients groups ROC curve

Fig. 1 A Serum ER (ng/ml) and E2 (pg/ml) in AML and ALL male patients groups ROC curve. B Serum ER (ng/ml) and E2 (pg/ml) in AML and ALL female patients groups ROC curve

different cancers, notably mass tumors such [24-27] for which anti-estrogens were tried in an attempt to cure these malignancies. Yet the estrogen and its soluble estrogen receptor clinical significance in acute leukemia patients have not been investigated. Our work hypothesizes that determining the E2 and soluble ER levels could provide valuable information in treating acute leukemia patients.

The non-steroidal anti-estrogens $[\mathrm{AE}]$ are a vast class of artificial compounds that are derived from triphenylethylene as tamoxifen. They are estrogen antagonists whose cellular effects are not merely by estrogenic blockade [28].

In cells of breast cancer, tamoxifen induces in vitro TGF-B1 and phospholipases expression activates cellular. It can arrest the BC cell cycle in G phase [29]. It has anti-angiogenic action is not interceded via ER [30].

Anti-estrogens $[\mathrm{AE}]$ exert oxidative stress, influencing calcium signaling [31], and conduct the action of variant receptors away of ER. Moreover, AEs induce apoptosis via caspase activity $[32,33]$ and antagonize drug resistance [28]. 
Hayon et al. [28] investigated the ER distinctive effects of anti-estrogens on ALL cell lines. Their findings revealed that anti-estrogens have growth inhibitory effects and by means of apoptosis and opposing of drug impedance.

These effects were confirmed when AEs were but together with other cytotoxic drugs. They added that cell cycle progression block may occur in leukemic cells ER deficient.

In the current work, we assessed the soluble ER in patients with acute leukemia. The mean soluble ER was lower in patients compared to the control in both AML and ALL patients. The low serum soluble ER in patients could reflect a low ER expression on leukemic cells.

Our findings especially in ALL patients whose ER levels were lower than AML agrees with, Hayon et al. [28] who reported that lymphoblastic cells do not express estrogen receptors and the anti-estrogens role in their study which involved apoptosis induction was ER independent. They found that nafoxidine, another antiestrogen, proved to be more potent than tamoxifen or clomiphene.

The difference between the three anti-estrogens could be due to affinity binding difference to anti-estrogen binding sites.

We could attribute the low level of ER in acute leukemias to possible methylation and consequently gene silencing. This has been revealed in previous studies which demonstrated that ERs expression could be controlled by genetic and epigenetic mechanisms in human cancers [34, 35].

Yao et al. [12], studied CPG promoter methylation of estrogen receptors in leukemia. They used RT-PCR and MSP-PCR in leukemia cell lines and direct DNA sequencing. They reported that only ER $\alpha$ was specifically methylated and inactivated nearly in all acute leukemia patients while no methylation in control group which agrees with our findings where serum ER was elevated in the control upon comparing with the leukemic patients. This highlights that silencing of the gene expressing ER by methylation can be important in pathogenesis of leukemia or it is partially depending on the carcinogenic insult that induced the neoplastic disease [12].

Cytosine methylation inactivates genes participate in neoplasia or tumor suppressor genes. The degree of hyper methylation is due to DNA methyltransferase upregulation.

In the current work, the range of serum level of soluble serum ER was variable and large and this could be explained by that not all AML subgroups do express the ER equally. We could postulate that the AML patient's different behavior is due to either the different leukemic subtypes or to the state of their cholesterol metabolism. Yom-Tov et al. [15] and de Medina et al. [36] stated that anti-estrogen can function as a ligand for anti-estrogen binding microsomal site, generating cell death through cholesterol metabolism regulation.

In addition, the degree of methylation in AML patients all subtypes is not the same. Toyota et al. [37] studied the aberrant methylation profile in AML. They deduced that hyper methylation of some genes associated with reduced levels of their expression and they found that age inversely correlated with the number of methylated genes. This agrees with our study, as we reported an inverse significant correlation between the mean serum ER level and age, yet it was only for male patients, we could not establish this correlation in females whether AML or ALL.

This elucidate relation between methylation and age is significant in older patients retain little genes methylated and that of AML biology in elderly is totally unlike AML young patients. This agrees with Qingli et al. who found a negative association between age and ER this reflects that AML biology in adults is different from that in elderly or the different triggering factors that led to AML.

As regards the serum ER levels was lower in M4 and M5 male patients compared to other subtypes in males yet the difference was not statistically significant.

This could be interpreted by the small sample size or different cell of origin in M4 and M5. Yet, in female patients, the mean level of serum ER in M4 and M5 patients was higher than the other subtypes. This indicates that the different levels of serum ER with specific subtypes highlight different methylation levels.

Moreover, the serum ER lower level in ALL compared to AML patients could be attributed to the occurrence of hyper ethylating phenotypes in ALL than in AML.

This agrees with Toyota et al. [37] whose preliminary data suggested the occurrence of hyper methylation phenotypes in ALL reflecting different gene expression profiles, implying the presence of specific carcinogenic insults such as radiation exposure or previous cytotoxic chemotherapeutic drugs.

In the current work, significant elevated ALT and AST levels were reported in patients versus the control. This was notable in ALL compared to AML patients reflecting that the leukemic impact is more prominent on the liver in ALL patients. The same findings were reported in renal function tests which were more elevated in ALL than AML patients.

Soluble ER can be a biological marker of leukemia. ER $\alpha \mathrm{A}$ the isoform in comparison to other isoforms of ER was specifically and highly methylated in leukemic patients and was no methylation in controls [12]. Li et al. [38] added that the different levels of methylated ER reflect different exposure to carcinogenic insults.

In the current work, the estrogen level was elevated in the control than the patients and that was statistically 
significant both in AML and ALL males and females patients.

In the current work, the mean serum albumin was positively correlated with ER in AML male patients, and this was not the same in AML or ALL female patients.

In the current work, AML male patients had a lower ER level than females. This agrees with previous studies who found a higher ER methylation and subsequent lower level of ER among males. These findings reflect an association between ER levels with sex [37, 38].

The significant decline in serum of ER levels and E2 concentration in male and female patients groups with acute leukemias compared to their corresponding normal controls propose the capability of applying any one of these variables in acute leukemia diagnosis to distinguish the patients with acute leukemias from normal controls. This led us to compare the diagnostic power of these indices to decide which of decisive diagnostic value. This comparability also concerned with identification of the precision specificity and sensitivity for each parameter and their corresponding cut-off value. This comparability was achieved through ROC curve plotting in such a way that the greatest plot below the ROC curves consistent with superior diagnostic test.

Serum ER either in male or female patients showed the greater area below the curve $[0.926$ and 0.880 , respectively] followed by E2 [0.870 and 0.808 , respectively].

Cut-off values, specificity, and sensitivity for diagnostic power male and female patients with acute leukemia were $3.58 \mathrm{ng} / \mathrm{ml}, 90 \%, 96.3 \%$ and $1.67 \mathrm{ng} / \mathrm{ml}, 90 \%$, and $90 \%$ for ER and $25.9 \mathrm{pg} / \mathrm{ml}, 80 \%, 85.19 \%$ and $23.45 \mathrm{pg} /$ $\mathrm{ml}, 60 \%$, and $100 \%$ for E2, respectively.

These results indicate that serum ER is superior to serum E2 for diagnosis of male and female acute leukemia patients. Despite serum ER and E2 having been detected in acute leukemia patients, to our knowledge, this is the first work to compare diagnostic significance for serum ER with those of serum E2 with estimation of the precise cut-off value, specificity, and sensitivity of each parameter in acute leukemia patients.

\section{Conclusion}

1. The soluble ER in both males and AML and ALL females was lower significantly than the group of control.

2. Level serum E2 was lower in patients whether males or females than the control group.

3. ER level significantly positively correlated with hemoglobin concentration in AML male patients.

4. Total leukocytes count inversely correlated with ER level in AML male patients group.
5. Serum ER was significantly negative correlated with blast percent in ALL female patients group.

\section{Recommendations}

1. E2 and its soluble ER should be involved in the diagnostic workup to acute leukemia and especially the AML.

2. ER expression and methylation level should be studied especially in AML patients, in an attempt to target this receptor by anti-estrogens.

\section{Abbreviations}

AEs: Anti-estrogens; ALL: Acute lymphoblastic leukemia; ALT: Alanine aminotransferase; AML: Acute myeloid leukemia; AST: Aspartate aminotransferase; BM: Bone marrow; CpG: 5'Cytosine-phosphate-guanine3'; DNA: Deoxyribonucleic acid; E2: Serum estrogen; ELISA: Enzyme-linked immunosorbent assay; ER: Soluble estrogen receptor; $\mathrm{Hb}$ : Hemoglobin; MRI: Medical Research Institute; PLT: Platelet; ROC: Receiver operating characteristics; SPSS: Statistical Package for the Social Sciences; TGFB1: Transforming growth factor-beta1

\section{Acknowledgements}

Authors would like to thank all the patients and their families for participating in this project.

\section{Authors' contributions}

SE designed the research and EN interpreted the patient data regarding the hematological disease, management, and follow up. SA analyzed the data. NS processed the samples. All authors shared in writing the manuscript and read and approved the final manuscript.

\section{Funding}

This research did not receive any specific grant from funding agencies in the public, commercial, or not-for-profit sectors.

Availability of data and materials

Data and materials are available upon request.

\section{Declarations}

Ethics approval and consent to participate

The research methodology in the present work was approved by research ethical committee of Alexandria University (0304933, Alexandria, Egypt) and written informed consent was obtained from each participant enrolled in the study prior to sample collection. Experimental procedures and sampling followed the international and national regulations in accordance with the Declaration of Helsinki.

Consent for publication

Not applicable

Competing interests

The authors declare that they have no competing interests.

\section{Author details}

${ }^{1}$ Department of Applied Medical Chemistry, Medical Research Institute, Alexandria University, Alexandria, Egypt. ${ }^{2}$ Department of Hematology, Medical Research Institute, Alexandria University, Alexandria, Egypt. ${ }^{3}$ Department of Internal Medicine, Hematology Unit, Faculty of Medicine, Alexandria University, Alexandria, Egypt.

Received: 10 February 2021 Accepted: 22 July 2021

Published online: 18 August 2021

\section{References}

1. Lichtman MA, Kipps TJ, Seligsohn votal. Acute Leukemia. In williams hematology, 8th edition. The McGraw Hill companies, Inc. 2010:736-739. 
2. Bloomfield CD, Caliguiri MA (2001) Molecular biology of leukemias. In: VT DV, Hellman S, Rosenberg SA (eds) Cancer: principles and practice of oncology. Lippincott Williams and Wilkins, Philadelphia, pp 2389-2404

3. Redaelli A, Laskin BL, Stephens JM, Botteman MF, Pashos CL (2005) A systematic literature review of the clinical and epidemiological burden of acute lymphoblastic leukaemia (ALL). Eur J Cancer Care (Engl) 14(1):53-62. https://doi.org/10.1111/j.1365-2354.2005.00513.x

4. Pui CH, Relling MV, Downing JR (2004) Mechanisms of disease. Acute lymphoblastic leukemia. N Engl J Med 350(15):1535-1548. https://doi.org/1 0.1056/NEJMra023001

5. Burnett AK, Venditti A (2010) Acute myeloid leukemia. In: Hoffbrand AV, Cahovsky D, Tuddenham EG, Green AR (eds) Postgraduate haematology, 6th edn. Wiley-Blackwell, Oxford, pp 415-432

6. Druker BJ, Deschler B, Lübbert M (2006) Acute myeloid leukemia: epidemiology and etiology. Cancer 107:2099-2107

7. Döhner H, Estey EH, Amadori S, Appelbaum FR, Büchner T, Burnett AK, Dombret H, Fenaux P, Grimwade D, Larson RA, Lo-Coco F, Naoe T, Niederwieser D, Ossenkoppele GJ, Sanz MA, Sierra J, Tallman MS, Löwenberg B, Bloomfield CD, European LeukemiaNet (2010) Diagnosis and management of acute myeloid leukemia in adults: recommendations from an international expert panel, on behalf of the European LeukemiaNet. Blood 115(3):453-474. https://doi.org/10.1182/blood-2009-07-235358

8. Hewitt RE (2011) Biobanking: the foundation of personalized medicine. Curr Opin Oncol 23(1):112-119. https://doi.org/10.1097/CCO.0b013e32834161b8

9. Shim GJ, Wang L, Andersson S, Nagy N, Kis LL, Zhang Q, Makela S, Warner M, Gustafsson JA (2003) Disruption of the estrogen receptor beta gene in mice causes myeloproliferative disease resembling chronic myeloid leukemia with lymphoid blast crisis. Proc Natl Acad Sci USA 100(11):66946699. https://doi.org/10.1073/pnas.0731830100

10. Kouro T, Medina KL, Oritani K, Kincade PW (2001) Characteristics of early murine B-lymphocyte precursors and their direct sensitivity to negative regulators. Blood 97(9):2708-2715. https://doi.org/10.1182/blood.V97.9.2708

11. Issa JP, Zehnbauer BA, Civin Cl, Collector MI, Sharkis SJ, Davidson NE, Kaufmann SH, Baylin SB (1996) The estrogen receptor CpG island is methylated in most hematopoietic neoplasms. Cancer Res 56(5):973-977

12. Yao J, Huang Q, Zhang XB, Fu WL (2009) Promoter CpG methylation of oestrogen receptors in leukaemia. Biosci Rep 29(4):211-216. https://doi. org/10.1042/BSR20080140

13. Erlandsson MC, Ohlsson C, Gustafsson JA, Carlsten H (2001) Role of oestrogen receptors alpha and beta in immune organ development and in oestrogen-mediated effects on thymus. Immunology 103(1):17-25. https:// doi.org/10.1046/j.1365-2567.2001.01212.x

14. Stoetzer OJ (2012) Clomiphene treatment of acute myeloid leukemia. Leuk Res 36(1):27-28. https://doi.org/10.1016/j.leukres.2011.09.010

15. Yom-Tov G, Nathan I, Shpilberg O, Polliack A, Levi I (2012) Clomiphene as a novel modality for the treatment of acute myeloid leukemia: a pilot phase ॥ study. Leuk Res 36(1):42-45. https://doi.org/10.1016/j.leukres.2011.08.015

16. Bain BJ, Lewis SM, Bates I (2001) Basic haematological techniques. In: Lewis SM, Bain BJ, Bates I, Dacie J (eds) Dacie and Lewis's practical haematology, 9th edn. Churchill, Livingston, New York, pp 19-46

17. Huang XJ, Choi YK, Im HS, Yarimaga O, Yoon E, Kim HS (2006) Aspartate aminotransferase [AST/GOT] and alanine aminotransferase (ALT/GPT) detection techniques. Sensors 6(7):756-782. https://doi.org/10.3390/ s6070756

18. Burtis CA, Ashwood ER, Bruns DE (2008) Tietz fundamentals of clinical chemistry, 6th edn. Elsevier Saunders Company, St Louis

19. Khedr Y, Kotb M, Abd El-Kaream SA, El-Bayady O (2020) Assessment of some biochemical parameters and dielectric relaxations in $\beta$-Thalassemic children. Curr Appl Sci Technol 20(3):408-419

20. Burthem J, Bates I (2011) Bone marrow biopsy. In: Lewis SM, Bain BJ, Bates I, Dacie J (eds) Dacie and Lewis's practical haematology, 11th edn. Elselvier Ltd, Germany, pp 124-131

21. Ebied SAE, Sadek NA, Zaki NES, Abd El-Kaream SA, El Kashif HKA (2018) Prognostic value of soluble angiotensin II receptor 1 and soluble angiotensin converting enzyme [CD 143] in patients with acute leukemia. Acta Haematol Pol 49(4):240-250. https://doi.org/10.2478/ahp-2018-0028

22. Zwart W, de Leeuw R, Rondaij M, Neefjes J, Mancini MA, Michalides R (2010) The hinge region of the human estrogen receptor determines functional synergy between AF-1 and AF-2 in the quantitative response to estradiol and tamoxifen. J Cell Sci 123(8):1253-1261. https://doi.org/10.1242/jcs.06113 5
23. Tietz NW (1995) Clinical guide to laboratory tests, 3rd edn. Company: W.B Saunders, Philadelphia, pp 216-217

24. Chow PK, Tai BC, Tan CK, Machin D, Win KM, Johnson PJ, Soo KC, AsianPacific Hepatocellular Carcinoma Trials Group (2002) High-dose tamoxifen in the treatment of inoperable hepatocellular carcinoma: a multicenter randomized controlled trial. Hepatology 36(5):1221-1226. https://doi.org/1 0.1053/jhep.2002.36824

25. McClay EF, McClay ME, Monroe L, Baron PL, Cole DJ, O'Brien PH et al (2000) The effect of tamoxifen and cisplatin on the disease-free and overall survival of patients with high risk malignant melanoma. Br J Cancer 83(1):16-21. https://doi.org/10.1054/bjoc.1999.1220

26. Tropé C, Marth C, Kaern J (2000) Tamoxifen in the treatment of recurrent ovarian carcinoma. Eur J Cancer 36:56-61

27. Brandes AA, Pasetto LM, Monfardini S (2000) New drugs in recurrent high grade gliomas. Anticancer Res 20(3B):1913-1920

28. Hayon T, Atlas L, Levy E, Dvilansky A, Shpilberg O, Nathan I (2003) Multifactorial activities of nonsteroidal antiestrogens against leukemia. Cancer Detect Prev 27(5):389-396. https://doi.org/10.1016/S0361-090X(03 )00102-8

29. Cariou S, Donovan JC, Flanagan WM, Milic A, Bhattacharya N, Slingerland JM (2000) Down-regulation of p21WAF1/CIP1 or p27Kip1 abrogates antiestrogen-mediated cell cycle arrest in human breast cancer cells. Proc Natl Acad Sci USA 97(16):9042-9046. https://doi.org/10.1073/pnas.16001 6897

30. Obrero M, Yu DV, Shapiro DJ (2002) Estrogen receptor-dependent and estrogen receptor-independent pathways for tamoxifen and 4hydroxytamoxifen-induced programmed cell death. J Biol Chem 277(47): 45695-45703. https://doi.org/10.1074/jbc.M208092200

31. Zhang W, Couldwell WT, Song H, Takano T, Lin JH, Nedergaard M (2000) Tamoxifen-induced enhancement of calcium signaling in glioma and MCF-7 breast cancer cells. Cancer Res 60(19):5395-5400

32. Mandlekar S, Hebbar V, Christov K, Kong AN (2000) Pharmacodynamics of tamoxifen and its 4-hydroxy and N-desmethyl metabolites: activation of caspases and induction of apoptosis in rat mammary tumors and in human breast cancer cell lines. Cancer Res 60(23):6601-6606

33. Mandlekar S, Kong AN (2001) Mechanisms of tamoxifen-induced apoptosis. Apoptosis 6(6):469-477. https://doi.org/10.1023/A:1012437607881

34. Abd El-Kaream SA, Ebied SA, Sadek NA, Attia KA, Nadwan EA (2021) Serum estrogen and its soluble receptor levels in Egyptian patients with whronic myeloid leukemia: A case-control study. Indian J Hematol Blood Transfus. https://doi.org/10.1007/s12288-021-01451-8

35. Pinzone JJ, Stevenson H, Strobl JS, Berg PE (2004) Molecular and cellular determinants of estrogen receptor alpha expression. Mol Cell Biol 24(11): 4605-4612. https://doi.org/10.1128/MCB.24.11.4605-4612.2004

36. de Medina P, Paillasse MR, Segala G, Khallouki F, Brillouet S, Dalenc F et al (2011) Importance of cholesterol and oxysterols metabolism in the pharmacology of tamoxifen and other AEBS ligands. Chem Phys Lipids 164(6):432-437. https://doi.org/10.1016/j.chemphyslip.2011.05.005

37. Toyota M, Kopecky KJ, Toyota MO, Jair KW, Willman CL, Issa JP (2001) Methylation profiling in acute myeloid leukemia. Blood 97(9):2823-2829. https://doi.org/10.1182/blood.V97.9.2823

38. Li Q, Kopecky K, Mohan A, Willman CL, Appelbaum FR, Weick JK, Issa JP (1999) Estrogen receptor methylation is associated with improved survival in adult acute myeloid leukemia. Clin Cancer Res 5(5):1077-1084

\section{Publisher's Note}

Springer Nature remains neutral with regard to jurisdictional claims in published maps and institutional affiliations. 